\title{
THE EFFECT OF DIET ENRICHED WITH PYROPHOSPHATE (E450) ON EXPRESSION OF GENES ENCODING BONE MORPHOGENETIC PROTEIN AND OSTEOCALCIN IN MOUSE EMBRYONIC MANDIBLE TISSUES
}

10.36740/WLek202101108

\author{
Inessa I. Yakubova' ${ }^{1}$ Victor E. Dosenko ${ }^{2}$, Lesya V. Tumanovska², Volodymyr I. Ostrianko ${ }^{3}$ \\ ${ }^{1}$ KYIV MEDICAL UNIVERSITY, KYIV, UKRAINE \\ ${ }^{2}$ THE BOGOMOLETZ INSTITUTE OF PHYSIOLOGY NAS OF UKRAINE, KYIV, UKRAINE \\ ${ }^{3}$ SHUPYK NATIONAL MEDICAL ACADEMY OF POSTGRADUATE EDUCATION, KYIV, UKRAINE
}

\begin{abstract}
The aim: Of our study was to measure the mRNA expression of the investigated odontogenesis factors in mandible tissue of mouse embryos (17 ${ }^{\text {th }}$ day of pregnancy) gestated by females, kept on a $E 450$ rich diet since 30 days before fertilization to gestation.

Materials and methods: The effect of food supplements was studied in «0verload phosphates model». Experiments were carried out on white nonlinear outbred mice with mass $25-28 \mathrm{~g}(\mathrm{n}=40)$. The females from the control group were fed with standard rodent food, whereas the experimental females were fed with pyrophosphate-enriched food. The materials, used for the molecular genetic study, were the lower jaws of 17-days old mouse embryos ( $E-17)$.

Results: The investigated BMP2 and osteocalcin genes are expressed at approximately the same level. Pyrophosphate-rich diet does not alter BMP2 gene expression, but it significantly increases the expression of osteocalcin.
\end{abstract}

Conclusions: The present study is the first one to describe the impact of the pyrophosphate-rich diet on mRNA expression of key osteogenesis regulators - osteocalcin and BMP2.

KEY WORDS: Bone morphogenetic protein 2 (BMP2) expression, osteocalcin expression, lower jaws of mouse embryos, pyrophosphate-rich diet, food additive E450

Wiad Lek. 2021;74(1):43-47

\section{INTRODUCTION}

An optimized and well-balanced prenatal diet is essential for the physiological fetal development and formation of oral cavity organs and tissues in embryos $[1,2]$. Negative effects of food preservatives and colorings on human health, especially during pregnancy, are among greatest health concerns of our time $[3,4]$.

The World Health Organization (WHO) defines food additives as chemical substances and natural compounds, which are added to alimentary products for improvement in raw materials and end product quality. In Ukraine, the following definition (which does not go beyond the WHO one) is adopted: food additives are natural or artificial substances and their compounds, which are added to alimentary products at the production stage to give them specific properties and (or) preserve their quality.

Food additives are substances added to alimentary products due to the processing reasons, namely for preservation of organoleptical properties and extension of shelf life.

The food additives consumption by the population has significantly increased in recent years. This is due primarily to the expansion of the list of substances authorized for addition to food. A big deal of daily use products contains some amount of food additives (cereal and meat products, cheeses, oils, mayonnaise, NA beverages, confectionary goods). The world production of food additives is continuously increasing, both quantitatively and qualitatively: by $10-15 \%$ in Asia, by $4,4 \%$ in the USA, and only by $2 \%$ in Europe [5].

We focused our attention on one of the stabilizers, encoded E450, which is a pyrophosphate $\mathrm{H}_{4} \mathrm{P}_{2} \mathrm{O}_{7}$ and it is authorized as a stabilizing agent, though in some countries it is classified as hazardous to health [6]. It can be found in meat products, sausages, bacons, semi-finished products, jam, condensed milk, chocolate and processed cheese spreads, lemonade, sugary foods, etc [4]. Despite this, E450 is classified as a food additive, causing gastrointestinal and kidney diseases and calcium-phosphorus imbalance with further development of osteoporosis. It should be noted, however, that pyrophosphates are safe if consumed moderately [4].

Excessive intake of phosphates impairs calcium absorption [5], what can be crucial at the tooth bud mineralization stage [7]. The impact of maternal nutrition on the fetal odontogenesis has been well studied, but there are no studies dealing with teeth germination disorders, caused 
by excessive pyrophosphate (food additive E450) intake.

Of special interest are the studies, focusing on expression of the genes, the protein products of which play a crucial role in the mentioned processes at all stages of odontogenesis. Considerable attention is being paid to the bone morphogenetic protein (encoded by BMP2 gene) and the osteocalcin (Bglap gene) because of their dominant role in the calcification of a tooth bud $[8,9,10]$.

It was investigated, that the $B M P 2$, which is a growth factor for the tooth bud cells [11], promotes the differentiation of follicular cells into cementoblasts / -osteoblasts [12]. Such BMP2 action is caused by the expression of a number of genes (type I collagen, osteonectin, dentin sialophosphoprotein, nestin) in cells of dental pulp [13]. The expression of $B M P 2$ gene, in turn, is controlled by the growth hormone (somatotropin) and insulin-like growth factor-1, that both can increase the BMP2 expression in dental pulp fibroblasts in vitro in $4-5$ times [14]. Moreover, the differentiation of enamel organ cells is also regulated by growth factors, in particular by transforming growth factor alpha (TGF- $\alpha$ ) and epidermal growth factor (EGF) [15]. The BMP2 protein is able to activate the receptors of osteoblasts located on the tooth germ surface and stimulate the proliferation of dental pulp mesenchymal cells with following differentiation in odontoblasts, thus providing the formation of osteodentine and tubular dentine [14]. $B M P 2$ is predominantly expressed in epithelial cells at the early stage (up to $13^{\text {th }}$ day of a mouse embryo development) of tooth development. However, at the later stages it begins to be expressed mainly in the mesenchymal cells of dental papilla, initiating the intensification of dentinogenesis. Thus, BMP2 is responsible for dental mesenchyme cells' fate during the tooth formation [16].

Odontoblasts also synthesize calcium-binding proteins - osteocalcin and osteonectin, which are expressed in dentine as well as in bone tissue [15]. Osteocalcin belongs to the proteins containing three residues of $\gamma$-carboxyglutamic acid that binds free calcium and prevents the apatite formation. Osteocalcin is a vitamin K-dependent matrix protein, which is able to bind to hydroxyapatites. It is synthesized by the dentine odontoblasts and it is a key factor in dental connective tissue mineralization [17].

We failed to find any published data regarding the effect of excessive pyrophosphates intake by a mouse female during pregnancy on mRNA expression of BMP2 and osteocalcin.

\section{THE AIM}

The aim of this study was to measure mRNA expression of these odontogenesis factors in mandible tissue of embryos $\left(17^{\text {th }}\right.$ day of pregnancy) gestated by females, kept on a E450 rich diet since 30 days before fertilization to gestation.

\section{MATERIALS AND METHODS}

In calculating the diet for the experimental mice group we have considered such data as: the actual nutrition of pregnant women, which was evaluated by questionnaire-polling method [1], recommended daily set of products for a pregnant woman ${ }^{1}$, the content of E450 in foodstuffs, M.A.C. ${ }^{2}$ of E450 in some foodstuffs ${ }^{3}$. Approximate daily set of products for a pregnant woman: $200 \mathrm{~g}$ of meat or fish, 1 liter of milk in any form, 100-150g of curd, 20-30g of cheese, $1 \mathrm{egg}, 600 \mathrm{~g}$ of vegetables, 200-300g of fruits.

The effect of this food additive was studied in "phosphate overload model» (we add $2 \mathrm{~g}$ of E450 (sodium pyrophosphate, Israel) per $100 \mathrm{~g}$ of standard rodent food). We did not apply for any modification to a basic model [18].

Experiments were carried out on white nonlinear outbred mice with mass $25-28 \mathrm{~g}(\mathrm{n}=40)$. All mice were separated into 2 groups: control group and experimental group. The females from the control group were fed with standard rodent food, whereas the experimental females were fed with pyrophosphate-enriched food ( $2 \%$ of pyrophosphate, Israel). Females in proestrus or estrus phase were kept with the males in proportion 4:1 30 days later. The presence of spermatozoa in the vaginal smear was considered as an indicator of fertilization and first day of pregnancy. Animals were fed with standard food (control group) or pyrophosphate rich food (experimental group). Pregnant mice ( $\mathrm{n}=6$ per group) were sacrificed by the carbon dioxide expose on the $17^{\text {th }}$ day of pregnancy $(E-17)$. Mousekins were sacrificed on day $2(D-2)$ or day $28(D-28)$ after the birth. Experiments were performed in accordance with the European Community Standards.

The material of the molecular-genetic study were the lower jaws of 17 -days old mouse embryos (E-17), since bone morphogenetic protein $2(B M P-2)$ and osteocalcin (encoded by Bglap) $[8,9,10]$ are crucial for the tooth bud calcification at all stages of odontogenesis, especially at the bell stage (period from 16.5 to 18.5 days of pregnancy) [19].

RNA samples were extracted from mandible tissue with phenol/chloroform using Sigma-Aldrich (USA) reagents. RNA concentration was measured by NanoDrop 1000 spectrophotometer by Thermo Scientific (USA). Reverse transcription was performed on 200-300 $\mu$ g of total RNA using First Strand cDNA Synthesis Kit (Fermentas, Lithuania) and (Oligo $(\mathrm{dT})_{18}$ Primer. The resulting cDNA product was used for PCR amplification. Quantification of BMP2 and bone gamma carboxyglutamate protein (Bglap, osteocalcin) expression was performed by real-time PCR using primers shown below:

BMP2 Up: 5 '-GTGGAGGAACTTCCAGAGATGA-3`; BMP2 Dw: 5 '-CTGCAGATGTGAGAAACTCGTC-3';

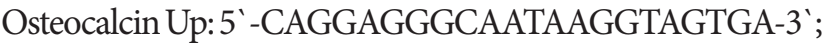

Osteocalcin Dw: 5 '-CAGGGTTAAGCTCACACTGCTC-3 .

\footnotetext{
${ }^{1}$ Maximum allowable concentration.

${ }^{2}$ Maximum allowable concentration of the food additive E450 in some foodstuffs: baked goods - $10000 \mathrm{mg} / \mathrm{kg}$, desserts - $3000 \mathrm{mg} / \mathrm{kg}$, ice cream - $1000 \mathrm{mg} / \mathrm{kg}$, flour - $2500 \mathrm{mg} / \mathrm{kg}$, raw eggs - $10000 \mathrm{mg} / \mathrm{kg}$, sauces - $5000 \mathrm{mg} / \mathrm{kg}$, processed cheese $-9000 \mathrm{mg} / \mathrm{kg}$, meat and fish products - from 100 to $5000 \mathrm{mg} / \mathrm{kg}$ ( $0.3 \%$ of the total weight of the forcemeat).

${ }^{3}$ The maximum acceptable daily consumption of E450 is $70 \mathrm{mg} / \mathrm{kg}$ body weight.
} 


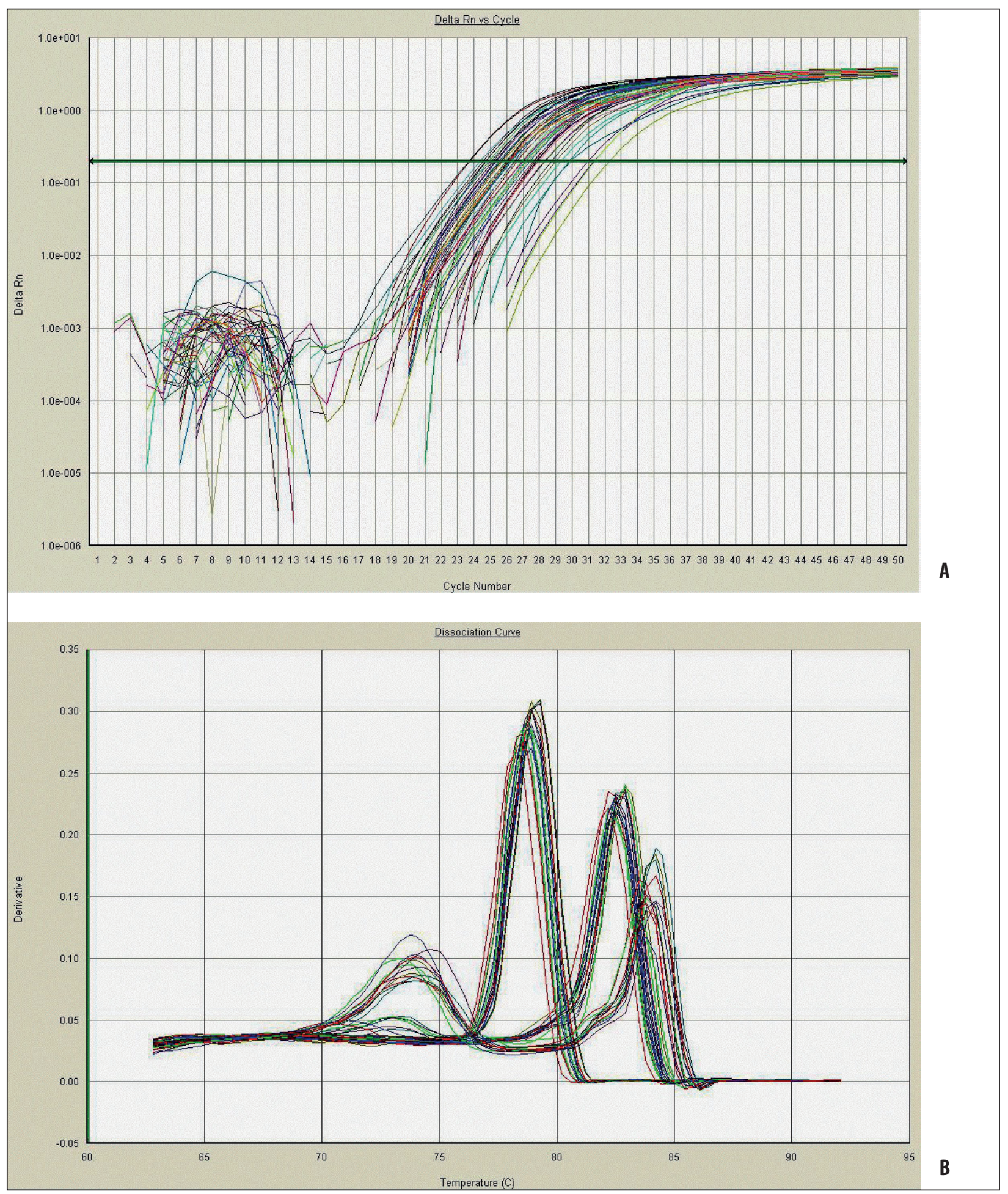

Fig. 1. Actin, BMP2 and osteocalcin amplification products concentration relative to amplification cycle number curve $(A)$ and amplification products dissociation curve (B).

PCR amplification reactions were performed in $20 \mu \mathrm{L}$ of SYBR Green PCR Master Mix containing 25 pM of each primer. Thermal cycling conditions comprised an initial denaturation and AmpliTaq Gold ${ }^{\oplus}$ DNA polymerase activation step at $95^{\circ} \mathrm{C}$ for $10 \mathrm{~min}$, followed by 50 cycles of denaturation for $15 \mathrm{~s}$ at $95^{\circ} \mathrm{C}$ and $60^{\circ} \mathrm{C}$ (or $61^{\circ} \mathrm{C}$, in case of osteocalcin gene) for $1 \mathrm{~min}$. In addition, melting curve analysis was performed to control the specificity of PCR product fluorescence: the sample was gradually heated from 60(61) to $94^{\circ} \mathrm{C}$ while simultaneously detecting decrease of DNA-SYBR Green complex fluorescence intensity.

Amplification products concentration vs cycle curve and amplification products dissociation curve are shown in fig. 1 . 


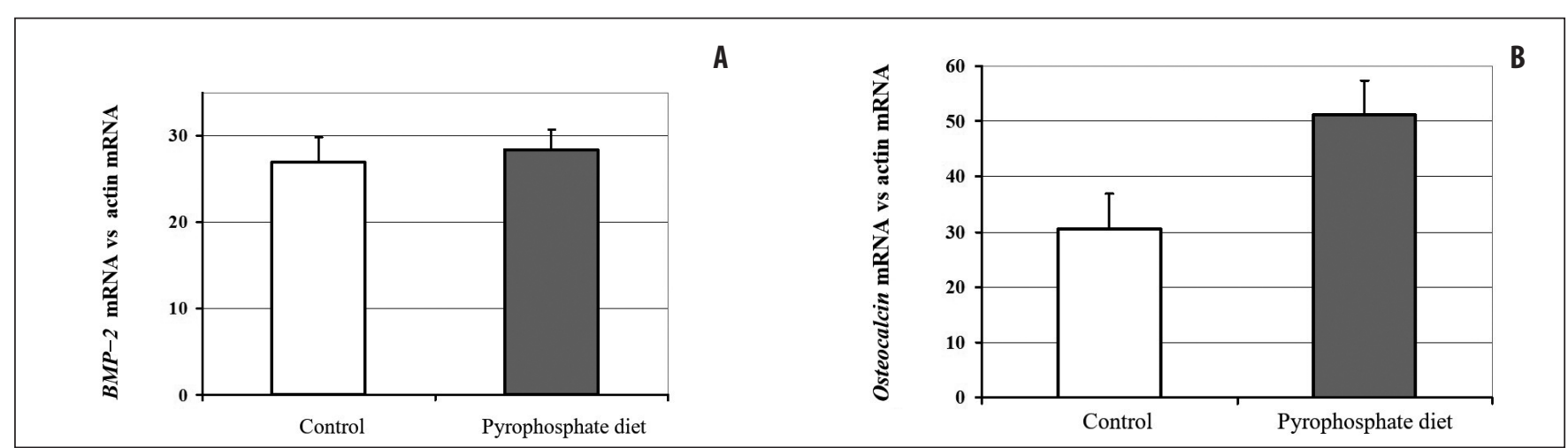

Fig. 2. BMP2 (A) and osteocalcin (B) mRNA expression relative to actin in lower jaw tissue of mouse embryos from control and experimental (high pyrophosphate diet) groups.

The analysis of the data received was performed using 7500 Fast Real-time PCR Software.

The extrapolation of the obtained results to humans is theoretically possible due to the great described genes sequence similarity between humans and mice $[20,21]$.

Statistical analysis. Statistical analysis of the digital data was performed using Excel 2000 and Origin 7.0. Probability distribution of mean $(\mathrm{P}<0.05)$ was calculated using Student's t-test.

\section{RESULTS AND DISCUSSION}

The expression of $B M P 2$ in jaws was the same in animals from control and experimental groups $(\mathrm{p}=0,71 ; \mathrm{p}>0,05)$. Nevertheless, pyrophosphate-enriched diet caused 1,8 fold increase of osteocalcin expression $(\mathrm{p}=0,047 ; \mathrm{p}<0,05)$ to $51,2 \pm 6,20$ (fig. 2 ).

The analysis of the data shows that a diet with high content of sodium pyrophosphate does not change the expression of $B M P 2$ gene. Given that $B M P 2$ is a key factor of odontoblasts differentiation [22], we can hypothesize that excessive pyrophosphate in maternal diet would not influence the odontogenesis in the embryo. However, sodium pyrophosphate rich diet is likely to increase the expression of osteocalcin. On the one hand, raised osteocalcin expression seems to be a positive sign, since osteocalcin ensures the mineralization of tooth bud tissues, and that means intensification of apatite formation in animals with gained expression of osteocalcin. But on the other hand, the hyperexpression of osteocalcin could cause the premature tooth mineralization that can disrupt the processes of teeth formation and odontogenesis all in all.

Our results do not fully agree with those in the study [23], where the authors researched the effect of inorganic phosphate/pyrophosphate on expression of a wide range of genes (using real-time PCR) in mouse cementoblasts. It was investigated that pyrophosphate at the concentration of $5 \mathrm{mM}$ caused increase of ogosteopontin and dentin matrix protein-1 expression and decreased mRNA expression of bone sialoprotein (Bsp), osteocalcin and type I collagen. Differences in the results could be explained by the differences in selected methodology (experiments were conducted in vitro on isolated cells) and by briefness of pyrophosphate exposure (to 48 hours). Our study shows the effect of 50 days-long pyrophosphate exposure of the whole organism. We evaluated the gene expression in lower jaw tissues instead of using cultivated cells for this purpose. Nevertheless, the most important fact is that pyrophosphate can alter the expression of some genes significant for odontogenesis.

\section{CONCLUSIONS}

Thus, we first described the impact of pyrophosphate-enriched diet on mRNA expression of osteocalcin and BMP2 which are crucial regulators of osteogenesis. Further observations on histopathological changes in mouse tooth bud would give a possibility to match the genetic changes with the pathomorphological changes and clarify the functional role of the alterations in expression of the investigated genes.

\section{REFERENCES}

1. Kryzhalko O.V., Yakubova I.I., Kaskova L.F. Analiz danykh faktychnoho kharchuvannia sered vahitnykh zhinok i materiv, shcho hoduiut [Data analysis of actual nutrition among pregnant women and lactating mothers]. Materialy nauk.-prakt. konf. stomatolohiv Zakarpattia z mizhnar. uchastiu (16-17.04.2010). Uzhhorod. 2010: 171-173. (In Ukrainian).

2. Yakubova I.I. Chynnyky ryzyku vynyknennia kariiesu tymchasovykh zubiv u period zakladky i mineralizatsii [Risk factors for caries of deciduous teeth during mineralization and bookmarks]. Ukrainskyi stomatolohichnyi almanakh. 2012; 2(2): 81-85. (In Ukrainian).

3. Yakubova I. A compendium of facts on oral health of children around the world: early childhood caries, nova science publishers. New York, Usa. 2017: 405-418.

4. Ivashkiv L.la., Bomba M.la., Shakh A.le., Matskiv 0.0., Vivcharuk O.M. Analiz vmistu kharchovykh dobavok u produktakh kharchuvannia ta yikh nebezpeky dlia zdorovia spozhyvachiv [Analysis of the content of food additives in foods and their health risks to consumers]. Perspective innovations in science, education, production and transport '2013 Byolohyia- - kolohyia y Byotekhnolohyia. SWorld. 2013 http://www. sworld.com.ua/index.php/ru/conference/the-content-of-conferences/ archives-of-individual-conferences/dec-2013.

5. Smoliar V.I. Suchasni problemy vykorystannia kharchovykh dobavok [Modern problems of using nutritional supplements]. http://www. medved.kiev.ua/Web_journals/Arhiv/Nutrition/2009/1__09/str05.pdf. 
6. Commission regulation (EU) № 257/2010 of 25 March 2010 setting up a programme for the re-evaluation of approved food additives in accordance with Regulation (EC) No 1333/2008 of the European Parliament and of the Council on food additives. https://eur-lex.europa. eu/LexUriServ/LexUriServ.do?uri=0J:L:2010:080:0019:0027.

7. Yakubova I.I., Tumanovska L.V. Morfolohichni zminy zachatkiv zubiv u embrioniv myshei pid vplyvom kharchovoi dobavky E-450 [Morphological changes rudiments of teeth in embryos of mice under the influence of the food additive E-450]. Visnyk stomatolohii. 2012; 1(78): 15-19. (In Ukrainian).

8. Casagrande L., Demarco F.F., Zhang Z. et al. Dentin-derived BMP-2 and odontoblast differentiation. Journ. Dent. Res. 2010; 6(89): 603-608.

9. Linde A. Dentin matrix proteins: composition and possible functions in calcification. Anat. Rec. 1989; 2(224): 154-166.

10. Wise G.E. Cellular and molecular basis of tooth eruption. Orthod. Craniofac. Res. 2009; 2(12): 67-73.

11. Lesot H., Lisi S., Peterkova R. et al. Epigenetic signals during odontoblast differentiation. Adv. Dent. Res. 2001; 15: 8-13.

12. Milgrom P., Riedy C.A., Weinstein P. et al. Dental caries and its relationship to bacterial infection, hypoplasia, diet, and oral hygiene in 6- to 36-monthold children. Com. Dent. Oral. Epidemiol. 2000; 4(28): 295-306.

13. About I., Mitsiadis T.A. Molecular aspects of tooth pathogenesis and repair: in vivo and in vitro models. Adv. Dent. Res. 2001; 15: 59-62.

14. LiH.,Bartold P.M.,Zhang C.Z.etal. Growth hormone and insulin-like growth factor linduce bone morphogenetic proteins 2 and 4 : a mediator role in bone and tooth formation? Endocrinology. 1998; 9(139): 3855-3862.

15. Pykaliuk V.S., Osmanov A.Yu. Onto-, filohenez orhaniv i system [Onto-, phylogeny of organs and systems]. Simferopol. 2011:312. (In Ukrainian).

16. Chen S., Gluhak-Heinrich J., Martinez M. et al. Bone Morphogenetic Protein 2 Mediates Dentin Sialophosphoprotein Expression and Odontoblast Differentiation via NF-Y Signaling. Journ. Biol. Chem. 2008; 28(283): 19359-19370.

17. Takano-Yamamoto T., Takemura T., Kitamura Y. et al. Site-specific Expression of mRNAs for Osteonectin, Osteocalcin, and Osteopontin Revealed by In Situ Hybridization in Rat Periodontal Ligament During Physiological Tooth Movement. The Journ. of Histochemistry and Cytochemistry. 1994; 7(42): 885-896.

18. Rukovodstvo po laboratornym zhivotnym i al'ternativnym modeljam $v$ biomedicinskih tehnologijah [Guidance on laboratory animals and alternative models in biomedical technology]. N.N. Karkishhenko, Moskva. 2010. (In Russian).

19. Eberg T., Wozney J., Thesleff I. Expression patterns of bone morphogenetic proteins (bmps) in the developing mouse tooth suggest poles in morphogenesis and cell differentiation. Developmental Dynamics. 1997; 4(210): 383-396.
20. Thesleff I., Tummers M. Tooth organogenesis and regeneration. http:// www.stembook.org/node/551\#fn1

21. Bojarskij K.Ju. Molekuljarnye osnovy follikulogeneza: v 2 ch. Probl. reprodukcii.Ch.1.0t pervichnyh polovyh kletok do antral'nyh follikulov: obzor literatury [The molecular basis of folliculogenesis: in 2 hours Probl. reproductions. Part 1. From primary germ cells to antral follicles: literature review]. 2006; 4: 26-37. (In Russian).

22. Popowics T., Foster B.L., Swanson E.C. et al. Defining the roots of cementum formation. Cells Tissues Organs. 2005:3-4(181):248-257.

23. Foster B.L., Nociti F.H.Jr., Swanson E.C. et al. Regulation of cementoblast gene expression by inorganic phosphate in vitro. Calcif. Tissue Int. 2006; 2(78): 103-112.

The present study is a part of the research, undertaken by the Pediatric Dentistry Department of the Private Higher Educational Establishment "Kyiv Medical University»: «The Risk Assessment, Pathogenesis, Clinical Manifestations, Treatment and Prevention of Different Pediatric Dental Diseases» (state registration number 0112U008260).

\section{ORCID and contributionship:}

Inessa I. Yakubova: 0000-0003-2780-2460 A,B,C,D

Victor E. Dosenko: 0000-0002-6919-7724 A,C,E,F

Lesya V. Tumanovska: 0000-0002-7984-5270 ${ }^{C, E}$

Volodymyr I. Ostrianko: 0000-0001-6525-7526 B,C,E

\section{Conflict of interest:}

The Authors declare no conflict of interest.

\section{CORRESPONDING AUTHOR Inessa I. Yakubova \\ Kyiv Medical University \\ 17 M.Krasnova st., app. 130, 03115 Kyiv, Ukraine \\ tel: +380677132097 \\ e-mail:yakubova.inessa@gmail.com}

Received: 03.03 .2020

Accepted: 08.10 .2020

A - Work concept and design, B - Data collection and analysis, C - Responsibility for statistical analysis, D-Writing the article, $\mathbf{E}-$ Critical review, $\mathbf{F}$ - Final approval of the article 